\title{
PENGARUH PEMBERIAN BERBAGAI KONSENTRASI DAN JENIS PENGAWET ALAMI TERHADAP JUMLAH ANGKA KUMANDAN MASA SIMPAN IKAN MUJAIR TAHUN 2016
}

\author{
Aptiningsih $^{1)}$, Aris Santjaka ${ }^{2),}$ Hari Rudijanto ${ }^{3)}$ \\ Jurusan Kesehatan Lingkungan, Politeknik Kesehatan Kemenkes Semarang, \\ Jl. Raya Baturaden KM 12 Purwokerto, Indonesia
}

\begin{abstract}
Abstrak
Ikan mujair sebagai sumber protein yang baik secara alami, namun ikan ini mudah membusuk pada suhu kamar. Upaya pengawetan dibutuhkan untuk mempertahankan nilai gizi dan ekonomisnya. Masyarakat pedesaan masih banyak yang belum memiliki lemari pendingin karena berbagai keterbatasan, dengan demikian pengawet alami meliputi bawang putih, lengkuas dan jahe menjadi alternatif yang ada. Tujuan dari penelitian ini adalah mengetahui pengaruh pemberian berbagai jenis konsentrasi pengawet alami terhadap jumlah angka kuman dan masa simpan.Penelitian ini adalah eksperimen semu (Quasi Experiment) dengan rancangan postest dengan kelompok kontrol (non randomized posttest only control group design). Populasi dalam penelitian ini adalah semua ikan mujair yang dijual di Pasar ikan Purbalingga. Sampel Daging ikan mujair yang diberi perlakuan pengawet alami dengan konsentrasi tertentu dengan jumlah perlakuan sebanyak 9 (sembilan) perlakuan dan 1 (satu) kontrol. Replikasi pada penelitian ini sebanyak 3 (tiga) kali. Analisis data yang digunakan adalah analisis statistik manova dan anova oneway.Hasil analisis menunjukan bahwa ada pengaruh pemberian jenis pengawet alami terhadap jumlah angka kuman dengan nilai $p=0,044$ dan pemberian jenis pengawet alami juga ada pengaruhnya terhadap masa simpan dengan nilai $p=0,000$. Hasil analisis selanjutnya yaitu menunjukan bahwa konsentrasi pengawet alami juga ada pengaruhnya terhadap jumlah angka kuman dengan nilai $p=0,000$, serta konsentrasi pengawet alami juga ada pengaruhnya terhadap masa simpan dengan nilai $p=0,000$.Pengawet alami yang paling baik dalam menekan jumlah angka kuman dan meningkatkan masa simpan adalah bawang putih dengan konsentrasi $30 \mathrm{gr} / 100$ $\mathrm{ml}$, tetapi belum bisa digunakan untuk mengawetkan ikan dalam waktu 1x24 jam karena angka kumannya masih diatas batas maksimum BPOM. Peneliti lain dapat melakukan penelitian lanjutan yaitu dapat menggunakan variabel bebas yang berbeda seperti lama perendaman yang berbeda, konsentrasi yang berbeda ataupun dengan pengawet alami yang lain.
\end{abstract}

Kata Kunci : Pengawet Alami

\begin{abstract}
Mujair fish as a source of good proteins naturally, but these fish is easily decomposed at temperature room. The preservative efforts needed to maintain nutritional value and its economic. Villagers are still do not have a refrigerator because of , thus natural preservative covering garlic, ginger plant and ginger into the alternatives.The purpose of this research is aware the influence of various types of a preservative natural concentration on the number of points microbes and the savings.This researcher include of type of Quasi Experiment with of non randomized posttest only control group design. The population in this research all of mujair fish which sell in market of fish Pubalingga. The example of mujair fish which given treatment a natural preservative by concentration of the certain by the number of treatment as many as 9 (nine) treatment and 1 (one) control.Replication to research this about 3 (three) times. Analysis the data used was statistical analysis manova and anovaoneway.Theresult shows that the kind of natural preservative effect of the total number of germs with $p=0.044$ and delivery of this type of natural preservatives also have an effect on the shelf life with $p=0.000$. The Further results of analysis which shows that the concentration of natural preservatives also have an effect on the total number of germs with $p=0.000$, and the concentration of natural preservatives also have an effect on the shelf life withp $=0.000$. Natural preservative the good one in reducing the number of microbe and increase the saving is garlic with concentration $30 \mathrm{gr} / 100 \mathrm{mls}$, but could not used to preserve fish in time $1 \times 24$ hours because of the number still up its microbes the maximum limited BPOM.The other researchers can conduct research advance namely can use independent different variable as long immersion different, the different of concentration nor with another natural preservative
\end{abstract}

Keywords : Natural Preservative

1) Email : aptycant@yahoo.co.id

2) Email : arissantjaka@gmail.com

3) Email : hariokev2000@vahoo.com 


\section{I.PENDAHULUAN}

Ikan mujair sebagai salah satu sumber protein hewani yang banyak dikonsumsi oleh masyarakat. Ikan mujair memiliki sifat yang mudah mati dan mudah mengalami kerusakan yang diakibatkan oleh bakteri. Mudahnya kerusakan ikan tersebut menjadi kendala bagi masyarakat terutama yang tidak memiliki lemari pendingin, oleh karena itu perlu adanya upaya untuk mengawetkan ikan mujair tersebut sehingga masihd alam keadaan yang layak dikonsumsi dan aman. Pengawetan ikan mujair dasarnya adalah mempertahankan ikan mujair selama mungkin dengan cara menghambat atau menghentikan beberapa aktivitas bakteri pembusuk yang ada pada tubuh ikan mujair.

Pengawetan yang umumnya digunakan untuk mempertahankan kesegaran ikan dengan cara pendinginan, pengeringan dan penambahan suatu zat. Proses pengawetan dengan penambahan zat dapat berasal dari zat yang alami ataupun buatan. Masyarakat yang tidak memiliki lemari pendingin, dapat memanfaatkan pengawet alami diantaranya dengan menggunakan rempah-rempah seperti bawang putih, lengkuas dan jahe. Rempah-rempah tersebut sangat mudah diperoleh di seluruh Indonesia, selain itu rempah-rempah merupakan bumbu dapur yang sangat lazim digunakan di dalam masakan.

Bawang putih, lengkuas, dan jahe dapat digunakan karena memiliki sifat anti mikroba sehingga dapat digunakan untuk menghambat pertumbuhan bakteri penyebab kerusakan ikan. Bawang putih memiliki sifat anti mikroba dalam menghambat pertumbuhan jumlah bakteri didukung oleh penelitian Lingga dan Rustama pada tahun 2006 di Bandung yang menyatakan bahwa ekstrak bawang putih yang dilarutkan dalam air bersifat anti bakteri terhadap bakteri gram positif dan gram negatif, serta Wiryawan menyatakan bawang putih dapat menghambat pertumbuhan koloni bakteri pathogen. Lengkuas dan jahe memiliki kemampuan sebagai anti mikroba dalam menghambat pertumbuhan jumlah bakteri didukung oleh penelitian Eni Purwani dan Muwakhidah pada tahun 2008 di Universitas Muhammadiyah Surakarta.

Ikan mujair sebagai sumber protein yang baik secara alami, namun ikan ini mudah membusuk pada suhu kamar. Upaya pengawetan dibutuhkan untuk mempertahankan nilai gizi dan ekonomisnya.

Masyarakat pedesaan masih banyak yang belum memiliki lemari pendingin karena berbagai keterbatasan, dengan demikian pengawet alami meliputi bawang putih, lengkuas dan jahe menjadi alternatif yang ada.

Mengetahui pengaruh pemberian berbagai jenis konsentrasi pengawet alami terhadap jumlah angka kuman dan masa simpan ikan mujair.

\section{II.BAHAN DAN METODE}

Bahan-bahan yang digunakan dalam penelitian ini terdiri dari :
1. Ikan Mujair

2. Pengawet alami (Bawang putih, Lengkuas, Jahe)

3. Blander

4. Air putih matang

5. Timbangan

6. Gelas Ukur

7. Gelas

8. Pisau

Jenis penelitian ini adalah eksperimen semu (Quasi Experiment) dengan rancangan postest dengan kelompok kontrol (non randomized post test only control group design).

Analisis data yang digunakan pada penelitian ini adalah analisa statistik dengan multivariate anova (manova) yaitu untuk menganalisis secara bersamaan data yang memiliki jumlah variabel dependen dan variabel independen lebih dari satu, serta menggunakan analisa statistik dengan anova oneway yaitu menganalisis perbedaan varian pada berbagai perlakuan berbeda dengan subjek yang sama.

\section{III.HASIL DAN PEMBAHASAN}

\section{Deskripsi angka kuman dibedakan menurut jenis pengawet alami}

Hasil pengaruh pengawet alami terhadap angka kuman, hasilnya bawang putih memiliki kemampuan paling baik dalam menekan jumlah angka kuman pada daging ikan mujair dibandingkan dengan pengawet alami lengkuas dan jahe. Bawang putih dikatakan paling baik, karena dilihat dari jumlah ratarata angka kumannya paling sedikit. Kandungan allicin pada bawang putih terbukti lebih efektif sebagai bahan anti bakteri dibandingkan dengan kandungan fenol pada lengkuas dan kandungan gingerol, shagoal dan zingeberon pada jahe.

Tabel 1 Angka kuman dibedakan menurut jenis pengawet alami

\begin{tabular}{clc}
\hline No & $\begin{array}{c}\text { Jenis Pengawet } \\
\text { Alami }\end{array}$ & $\begin{array}{c}\text { Jumlah Rata2 Angka } \\
\text { Kuman (Ribuan) } \\
\text { (Koloni/gr) }\end{array}$ \\
\hline 1 & Bawang Putih & 3265,33 \\
2 & Lengkuas & 3900,22 \\
3 & Jahe & 5521,89 \\
4 & Kontrol & 28460 \\
\hline
\end{tabular}

\section{Deskripsi masa simpan dibedakan menurut jenis pengawet alami \\ Hasil analisis pengaruh pengawet alami terhadap} masa simpan, hasilnya bawang putih memiliki kemampuan yang paling baik dalam meningkatkan masa simpan daging ikan mujair dibandingkan dengan pengawet alami lengkuas dan jahe. Bawang putih dikatakan paling baik karna memiliki rata-rata waktu masa simpan yang paling lama.Kandungan allicin pada bawang putih terbukti lebih efektif sebagai bahan untuk meningkatkan masa simpan dibandingkan dengan kandungan fenol pada lengkuas dan kandungan gingerol, shagoal dan zingeberon pada jahe. 
Tabel 2 Masa simpan dibedakan menurut jenis pengawet alami

\begin{tabular}{llc}
\hline No & Jenis Pengawet Alami & $\begin{array}{c}\text { Rata-rata Masa } \\
\text { Simpan } \\
\text { (Jam) }\end{array}$ \\
\hline 1 & Bawang Putih & 21,78 \\
2 & Lengkuas & 20,89 \\
3 & Jahe & 9,7 \\
4 & Kontrol & 4 \\
\hline
\end{tabular}

\section{Deskripsi Angka Kuman dibedakan Menurut Konsentrasi}

Hasil analisis pengaruh konsentrasi pengawet alami terhadap jumlah angka kuman, hasil analisisnya konsentrasi pengawet alami 30 gr/ $100 \mathrm{ml}$ memiliki kemampuan yang paling baik dalam menekan jumlah angka kuman pada daging ikan

Tabel 3 Angka kuman dibedakan menurut jenis pengawet alami

\begin{tabular}{clc}
\hline No & \multicolumn{1}{c}{$\begin{array}{c}\text { Konsentrasi } \\
\text { Pengawet Alami }\end{array}$} & $\begin{array}{c}\text { Jumlah Rata-rata } \\
\text { Angka Kuman } \\
\text { (Ribuan) } \\
\text { (Koloni/gr) }\end{array}$ \\
\hline 1 & $10 \mathrm{gr} / 100 \mathrm{ml}$ & 9491,56 \\
2 & $20 \mathrm{gr} / 100 \mathrm{ml}$ & 1612,78 \\
3 & $30 \mathrm{gr} / 100 \mathrm{ml}$ & 1583,11 \\
4 & Kontrol & 28460 \\
\hline
\end{tabular}

\section{Deskripsi Masa Simpan dibedakan Menurut Konsentrasi}

Hasil analisis konsentrasi pengawet alami seperti dilihat pada tabel 4, hasil analisisnya konsentrasi 30 gr/ $100 \mathrm{ml}$ memiliki kemampuan yang paling baik dalam meningkatkan masa simpan pada daging ikan mujair dibandingkan dengan konsentrasi 10 gr/ 100 $\mathrm{ml}$ ataupun dengan konsentrasi $20 \mathrm{gr} / 100 \mathrm{ml}$.

Tabel 4 Masa simpan dibedakanmenurut konsentrasi

\begin{tabular}{clc}
\hline No & \multicolumn{1}{c}{$\begin{array}{c}\text { Konsentrasi } \\
\text { Pengawet Alami }\end{array}$} & $\begin{array}{c}\text { Rata-rata Masa } \\
\text { Simpan } \\
\text { (Jam) }\end{array}$ \\
\hline 1 & $10 \mathrm{gr} / 100 \mathrm{ml}$ & 14,89 \\
2 & $20 \mathrm{gr} / 100 \mathrm{ml}$ & 18 \\
3 & $30 \mathrm{gr} / 100 \mathrm{ml}$ & 19,56 \\
4 & Kontrol & 4 \\
\hline
\end{tabular}

\section{Hasil Analisis Manova}

Hasil analisis manova seperti dilihat pada tabel 5, hasil analisisnya ada pengaruh pemberian jenis pengawet alami terhadap jumlah angka kuman dengan nilai $\mathrm{p}=0,044$ dan pemberian jenis pengawet alami juga ada pengaruhnya terhadap masa simpan dengan nilai $p=0,000$. Hasil analisis selanjutnya yaitu menunjukan bahwa konsentrasi pengawet alami juga ada pengaruhnya terhadap jumlah angka kuman dengan nilai $\mathrm{p}=0,000$, serta konsentrasi pengawet alami juga ada pengaruhnya terhadap masa simpan dengan nilai $\mathrm{p}=0,000$. Hasil analisis manova juga menunjukan bahwa pengaruh penggunaan jenis pengawet alami dan konsentrasi terhadap jumlah angka kuman pada ikan mujair adalah sebesar 81,5\%.
Pengaruh penggunaan jenis pengawet alami dan konsentrasi terhadap masa simpan ikan mujair sebesar $95,7 \%$

Tabel 5 Hasil analisis manova

\begin{tabular}{|c|c|c|c|c|}
\hline $\begin{array}{cc}\text { No } & \begin{array}{c}\text { Yang di } \\
\text { Uji }\end{array}\end{array}$ & $\begin{array}{c}\text { Variabel } \\
\text { Depen-den }\end{array}$ & $\mathbf{F}$ & $\mathbf{p}$ & Kesimpulan \\
\hline \multirow{3}{*}{$\begin{array}{l}\text { Jenis } \\
\text { Pengawet } \\
\text { Alami }\end{array}$} & Angka & 3,622 & 0,04 & Ho ditolak \\
\hline & Kuman & & & \\
\hline & $\begin{array}{l}\text { Masa } \\
\text { Simpan }\end{array}$ & 257,55 & 0,00 & Ho ditolak \\
\hline \multirow[t]{2}{*}{$\begin{array}{l}2 \text { Konsen- } \\
\text { trasi }\end{array}$} & $\begin{array}{l}\text { Angka } \\
\text { Kuman }\end{array}$ & 55,56 & 0,00 & Ho ditolak \\
\hline & $\begin{array}{l}\text { Masa } \\
\text { Simpan }\end{array}$ & 28,58 & 0,00 & Ho ditolak \\
\hline
\end{tabular}

Hasil Uji Lanjut

1. Jenis Pengawet Alami terhadap Jumlah Angka Kuman

Hasil uji lanjut pengaruh jenis pengawet alami terhadap jumlah angka kuman seperti dilihat pada tabel 6 , hasil analisinya kemampuan bawang putih dibandingkan dengan jahe didalam menekan jumlah angka kuman ada perbedaan, yaitu lebih baik bawang putih dengan nilai $\mathrm{p}=0,016$. Kemampuan bawang putih dalam menekan jumlah angka kuman dibandingkan dengan lengkuas tidak ada perbedaan atau memiliki kemampuan yang sama dengan nilai $\mathrm{p}=0,471$. Hasil analisis selanjutnya kemampuan jahe dibandingkan dengan lengkuas yaitu tidak ada perbedaan atau memiliki kemampuan yang samadalam menekan jumlah angka kuman dengan nilai $\mathrm{p}=0,074$.

Tabel 6 Hasil uji lanjut jenis pengawet alami terhadap jumlah angka kuman

\begin{tabular}{|c|c|c|c|}
\hline No & $\begin{array}{c}\text { Perbandingan } \\
\text { Jenis Pengawet } \\
\text { Alami }\end{array}$ & $\begin{array}{c}\text { Mean } \\
\text { Difference }\end{array}$ & $\begin{array}{c}\text { Kesim- } \\
\text { pulan }\end{array}$ \\
\hline 1 & $\begin{array}{l}\text { Bawang Putih } \\
\text { dengan Jahe }\end{array}$ & $-2256,56^{*}$ & $\begin{array}{r}\text { 0,016Ho } \\
\text { ditolak }\end{array}$ \\
\hline 2 & $\begin{array}{l}\text { Bawang Putih } \\
\text { dengan Lengkuas }\end{array}$ & $-643,89$ & $\begin{array}{l}\text { 0,471 Ho } \\
\text { diterima }\end{array}$ \\
\hline 3 & $\begin{array}{l}\text { Jahe dengan } \\
\text { Lengkuas }\end{array}$ & 1621,67 & $\begin{array}{l}\text { 0,075Ho } \\
\text { diterima }\end{array}$ \\
\hline
\end{tabular}

2. Jenis Pengawet Alami terhadap Masa Simpan

Hasil uji lanjut pengaruh jenis pengawet alami terhadap jumlah angka kuman, hasil analisinya ada perbedaan antara kemampuan bawang putih dibandingkan dengan jahe dalam meningkatkan masa simpan yaitu lebih baik bawang putih dengan nilai $\mathrm{p}=0,000$. Kemampuan bawang putih dibandingkan dengan lengkuas tidak ada perbedaan atau memiliki kemampuan yang sama dalam meningkatkan lama masa simpan dengan nilai $p=0,146$, sedangkan kemampuan jahe dibandingkan dengan lengkuas dalam meningkatkan lama masa simpan juga ada perbedaan yaitu lebih baik lengkuas dengan nilai $\mathrm{p}=0,000$. 
Tabel 7 Hasil uji lanjut pengawet alami terhadap masa simpan

\begin{tabular}{clccc}
\hline No & $\begin{array}{c}\text { Perbandingan } \\
\text { Jenis Pengawet } \\
\text { Alami }\end{array}$ & $\begin{array}{c}\text { Mean } \\
\text { Difference }\end{array}$ & p & $\begin{array}{c}\text { Kesim- } \\
\text { pulan }\end{array}$ \\
\hline 1 & $\begin{array}{l}\text { Bawang Putih } \\
\text { dengan Jahe } \\
\text { Bawang Putih } \\
\text { dengan Lengkuas }\end{array}$ & $12,00^{*}$ & 0,00 & $\begin{array}{l}\text { Ho } \\
\text { ditolak }\end{array}$ \\
3 & 0,89 & 0,17 & $\begin{array}{l}\text { Ho } \\
\text { diterima }\end{array}$ \\
Jahe dengan & $-11,11^{*}$ & $0,00 \begin{array}{l}\text { Ho } \\
\text { dengkuas ditolak }\end{array}$ \\
\hline
\end{tabular}

3. Angka Kuman dibedakan Per- Jenis Pengawet Alami dan Konsentrasi

\section{a. Bawang Putih}

Hasil uji lanjut anova oneway pengaruh pemberian pengawet alami bawang putih dengan berbagai konsentrasi terhadap jumlah angka kuman, diperoleh hasil bahwa konsentrasi $10 \mathrm{gr} / 100 \mathrm{ml}$ dibandingkan dengan konsentrasi $20 \mathrm{gr} / 100 \mathrm{ml}$ ada perbedaan dalam menekan jumlah angka kuman, yaitu lebih baik konsentrasi $20 \mathrm{gr} /$ $100 \mathrm{ml}$ dengan nilai $\mathrm{p}=0,000$. Konsentrasi $10 \mathrm{gr} / 100 \mathrm{ml}$ dibandingkan dengan konsentrasi $30 \mathrm{gr} / 100 \mathrm{ml}$ ada perbedaan dalam menekan jumlah angka kuman yaitu lebih baik konsentrasi $30 \mathrm{gr} / 100 \mathrm{ml}$ dengan nilai $\mathrm{p}=0,000$. Hasil selanjutnya yaitu konsentrasi $20 \mathrm{gr} / 100 \mathrm{ml}$ dibandingkan dengan konsentrasi $30 \mathrm{gr} / 100 \mathrm{ml}$ tidak ada perbedaan/ memiliki kemampuan yang sama dalam menekan jumlah angka kuman dengan nilai $p=0,675$, jadi secara ekonomis lebih baik menggunakan bawang putih dengan konsentrasi $20 \mathrm{gr} / 100 \mathrm{ml}$ karna dibutuhkan bawang putih dengan jumlah yang lebih sedikit.

\section{b. Lengkuas}

Hasil uji lanjut anova oneway pengaruh pemberian pengawet alami lengkuas dengan berbagai konsentrasi terhadap jumlah angka kuman, diperoleh hasil bahwa konsentrasi $10 \mathrm{gr} / 100 \mathrm{ml}$ dibandingkan dengan konsentrasi $20 \mathrm{gr} / 100 \mathrm{ml}$ tidak ada perbedaan dalam menekan jumlah angka kuman dengan nilai $\mathrm{p}=0,001$. Konsentrasi 10 $\mathrm{gr} / 100 \mathrm{ml}$ dibandingkan dengan konsentrasi $30 \mathrm{gr} / 100 \mathrm{ml}$ juga ada perbedaan dalam menekan jumlah angka kuman dengan nilai $\mathrm{p}=0,001$. Hasil analisis selanjutnya yaitu konsentrasi $20 \mathrm{gr} / 100 \mathrm{ml}$ dibandingkan dengan konsentrasi $30 \mathrm{gr} / 100 \mathrm{ml}$ tidak ada perbedaan atau memiliki kemampuan yang sama dalam menekan jumlah angka kuman dengan nilai $\mathrm{p}=0,897$, karena itu secara ekonomis lebih baik menggunakan lengkuas dengan konsentrasi $20 \mathrm{gr} / 100 \mathrm{ml}$ karena dibutuhkan lengkuas dengan jumlah yang lebih sedikit.

\section{c. Jahe}

Hasil uji lanjut anova oneway pengaruh pemberian pengawet alami jahe dengan berbagai konsentrasi terhadap jumlah angka kuman, diperoleh hasil bahwa konsentrasi $10 \mathrm{gr} / 100 \mathrm{ml}$ dibandingkan dengan konsentrasi $20 \mathrm{gr} / 100 \mathrm{ml}$ ada perbedaan dalam menekan jumlah angka kuman dengan nilai $\mathrm{p}=0,002$. Konsentrasi $10 \mathrm{gr} /$ $100 \mathrm{ml}$ dibandingkan dengan konsentrasi 30 gr/ $100 \mathrm{ml}$ juga ada perbedaan dalam menekan jumlah angka kuman dengan nilai $\mathrm{p}=0,003$. Hasil selanjutnya yaitu konsentrasi $20 \mathrm{gr} / 100 \mathrm{ml}$ dibandingkan dengan konsentrasi 30 gr/ $100 \mathrm{ml}$ tidak ada perbedaan atau memiliki kemampuan yang sama dalam menekan jumlah angka kuman dengan nilai $p=0,943$, jadi secara ekonomis lebih baik menggunakan jahe dengan konsentrasi $20 \mathrm{gr} / 100 \mathrm{ml}$ karna jahe yang dibutuhkan lebih sedikit.

4. Masa Simpan dibedakan Per- Jenis Pengawet Alami dan Konsentrasi

\section{a. Bawang Putih}

Hasil uji lanjut anova oneway pengaruh pemberian pengawet alami bawang putih dengan berbagai konsentrasi terhadap masa simpan, diperoleh hasil konsentrasi $10 \mathrm{gr} /$ $100 \mathrm{ml}$ dibandingkan dengan konsentrasi 20 gr/ $100 \mathrm{ml}$ ada perbedaan dalam meningkatkan masa simpan dengan nilai $\mathrm{p}=0$,003. Konsentrasi $10 \mathrm{gr} / 100 \mathrm{ml}$ dibandingkan dengan konsentrasi 30 gr/ 100 $\mathrm{ml}$ ada perbedaan dalam meningkatkan masa simpan dengan nilai $\mathrm{p}=0,000$. Hasil selanjutnya yaitu dengan konsentrasi $20 \mathrm{gr} /$ $100 \mathrm{ml}$ dibandingkan dengan konsentrasi 30 gr/ $100 \mathrm{ml}$ juga ada perbedaan dalam meningkatkan masa simpan dengan nilai $\mathrm{p}=0,010$. Hasil tersebut menunjukan bahwa semakin tinggi konsentrasi bawang putih, maka masa simpan akan semakin lama.

\section{b. Lengkuas}

Hasil uji lanjut anova oneway pengaruh pemberian pengawet alami lengkuas dengan berbagai konsentrasi terhadap masa simpan, diperoleh hasil konsentrasi 10 gr/ $100 \mathrm{ml}$ dibandingkan dengan konsentrasi 20 gr/ 100 ml tidak ada perbedaan atau memiliki kemampuan yang sama dalam meningkatkan masa simpan dengan nilai $\mathrm{p}=0,154$. Konsentrasi $10 \mathrm{gr} / 100 \mathrm{ml}$ dibandingkan dengan konsentrasi $30 \mathrm{gr} / 100 \mathrm{ml}$ ada perbedaan atau memiliki kemampuan yang berbeda dalam meningkatkan masa simpan dengan nilai $\mathrm{p}=0,050$. Hasil analisis selanjutnya yaitu konsentrasi 20 gr/ $100 \mathrm{ml}$ dibandingkan dengan konsentrasi 30 gr/ 100 $\mathrm{ml}$ tidak ada perbedaan atau memiliki 
kemampuan yang sama dalam meningkatkan masa simpan dengan nilai $\mathrm{p}=0,445$, jadi secara ekonomis lebih baik menggunakan lengkuas dengan konsentrasi 20 gr/ 100 ml karena lengkuas yang dibutuhkan jumlahnya lebih sedikit.

\section{c. Jahe}

Hasil uji lanjut anova oneway pengawet alami jahe dengan berbagai konsentrasi terhadap masa simpan, diperoleh hasil konsentrasi 10 gr/ $100 \mathrm{ml}$ dibandingkan dengan konsentrasi $20 \mathrm{gr} / 100 \mathrm{ml}$ ada perbedaan dalam meningkatkan masa simpan dengan nilai $\mathrm{p}=0,002$. Konsentrasi $10 \mathrm{gr} / 100 \mathrm{ml}$ dibandingkan dengan konsentrasi $30 \mathrm{gr} / 100 \mathrm{ml}$ ada perbedaan dalam meningkatkan masa simpan dengan nilai $\mathrm{p}=0,000$. Hasil analisi selanjutnya yaitu konsentrasi $20 \mathrm{gr} / 100 \mathrm{ml}$ dibandingkan dengan konsentrasi 30 gr/ 100 ml tidak ada perbedaan/ memiliki kemampuan yang sama dalam meningkatkan masa simpan, jadi secara ekonomis lebih baik menggunakan jahe dengan konsentrasi 20 gr/ $100 \mathrm{ml}$ karena jahe yang dibutuhkan jumlahnya lebih sedikit.

\section{IV.KESIMPULAN}

1. Jumlah angka kuman pada daging ikan mujair yang tidak menggunakan pengawet alami dan didiamkan selama 1x24 jam adalah sebesar 14.720.000 koloni/ gram.

2. Rata-rata jumlah angka kuman pada 100 gr daging ikan mujair yang direndam dengan larutan bawang putih selama 1 jam dengan konsentrasi $10 \mathrm{gr} / 100 \mathrm{ml}, 20 \mathrm{gr} / 100 \mathrm{ml}, 30 \mathrm{gr} /$ $100 \mathrm{ml}$ dan didiamkan selama 1x24 jam adalah masing-masing sebesar $7.620 .000 \mathrm{koloni} /$ gram, 1.283.000 koloni/ gram, 893.000 koloni/ gram.

3. Rata-ratajumlahangkakumanpada 100 gr dagingikanmujair yangdirendam dengan larutan lengkuas selama1 jam dengankonsentrasi10 gr/100 ml, 20gr/ $100 \mathrm{ml}, 30 \mathrm{gr} / 100 \mathrm{ml}$ dan didiamkan selama 1x24 jam adalah masingmasing sebesar 8.453.000 koloni/ gram, 1.551 .000 koloni/ gram, $1.696 .000 \mathrm{koloni} /$ gram.

4. Rata-rata jumlah angka kuman pada 100 gr daging ikan mujair yang direndam dengan larutan jahe selama 1 jam dengan konsentrasi 10 gr/100 ml, 20gr/ $100 \mathrm{ml}, 30 \mathrm{gr} / 100 \mathrm{ml}$ dan didiamkan selama $1 \times 24$ jam adalah masingmasing sebesar 12.400 .000 koloni/ gram, 2.004.000 koloni/ gram, 2.160.000 koloni/ gram.

5. Rata-rata masa simpan pada 100 gr daging ikan mujair yang direndam dengan larutan bawang putih selama 1 jam dengan konsentrasi $10 \mathrm{gr} / 100$ ml, 20gr/ $100 \mathrm{ml}, 30 \mathrm{gr} / 100 \mathrm{ml}$ adalah masingmasing selama 19,3 jam, 22 jam, dan 24 jam.
6. Rata-rata masa simpan pada 100 gr daging ikan mujair yang direndam dengan larutan lengkuas selama 1 jam dengan konsentrasi $10 \mathrm{gr} / 100 \mathrm{ml}$, 20gr/ $100 \mathrm{ml}, 30 \mathrm{gr} / 100 \mathrm{ml}$ adalah masingmasing selama 18,6 jam, 21,3 jam, dan 22,6 jam.

7. Rata-rata masa simpan pada100 gr dagingikanmujair yang direndam dengan larutan jaheselama1 jam dengankonsentrasi10 gr/100 ml, 20gr/ $100 \mathrm{ml}, 30 \mathrm{gr} / 100 \mathrm{ml}$ adalah masingmasing selama 6,6 jam, 10,6 jam, dan 12,6 jam.

8. Jenis pengawet alami diantara bawang putih, jahe dan lengkuas yang paling baik dalam menekan jumlah angka kuman adalah bawang putih.

9. Jenis pengawet alami diantara bawang putih, jahe dan lengkuas yang paling baik dalam meningkatkan masa simpan adalah bawang putih.

10. Konsentrasi pengawet alamidiantara $10 \mathrm{gr} / 100$ $\mathrm{ml}, 20 \mathrm{gr} / 100 \mathrm{ml}$ dan $30 \mathrm{gr} / 100 \mathrm{ml}$ yang paling baik digunakan untuk menekan jumlah angka kuman adalah konsentrasi 30 gr/ $100 \mathrm{ml}$.

11. Konsentrasi pengawet alami diantara $10 \mathrm{gr} / 100$ $\mathrm{ml}, 20 \mathrm{gr} / 100 \mathrm{ml}$ dan $30 \mathrm{gr} / 100 \mathrm{ml}$ yang paling baik digunakan untuk meningkatkan masa simpan dalah konsentrasi 30 gr/ $100 \mathrm{ml}$.

\section{V.DAFTAR PUSTAKA}

Ana Suryawati, Wulandari Meikawati, Rahayu Astuti, 2011, Pengaruh Dosis Dan Lama Perendaman Larutan Lengkuas Terhadap Jumlah Bakteri Ikan Bandeng, Jurnal Ilmiah, Semarang : Universitas Muhammadiyah Semarang

Annisa Rahmiatai Khasanah, 2008, Pengaruh Pemberian Bawang Putih (Allium sativum) Terhadap Keawetan Daging Ikan Cakalang (Katsuwonuspelamisdi Desa Karangmangu Kecamatan Baturraden Kabupaten Banyumas Tahun 2008, Karya Tulis Ilmiah, Purwokerto : Politeknik Kesehatan Depkes Semarang Jurusan Kesehatan Lingkungan Purwokerto.

Aris Santjaka, 2008, Statistik untuk Penelitian Kesehatan, Yogyakarta : Nuha Medika. 2015, Aplikasi SPSS untuk Analisis Data Penelitian Kesehatan, Yogyakarta : Nuha Medika.

BPOM RI, 2009, Peraturan Kepala Badan Pengawas Obat dan Makanan Republik Indonesia Nomor HK.00.06.1.52.4011 tentang Batas Maksimum Cemaran Mikroba dan Kimia dalam Makanan, Jakarta : BPOM RI. 
Eni Purwani, dkk, 2012, Karakteristik Daya Hambat Bakteri Perusak Pangan Hasil Isolasi dari Ikan Nila Oleh Ekstrak Jahe Dengan Pengencer Emulsi Tween 80, Surakarta : Universitas Muhammadiyah Surakarta

Hernawan UE \& AD Setyawan, 2003, Senyawa Organosulfur Bawang Putih (Allium sativum L.) dan Aktivitas Biologinya, Surakarta : Biofarmasi.

http://balittro.litbang.pertanian.go.id/Botani,

Sistematika dan Keragaman Kultivar Jahe, 29 Januari 2015 : 08.25 PM

Indonesia, Depkes RI, 1998, Pedoman Pengawasan Kualitas Makanan Terjemahan Ditjen PPM dan PLP, Jakarta: Ditjen PPM dan PLP Depkes RI

Lingga ME \& MM Rustama, 2005, Uji Aktivitas Antibakteri dari Ekstrak Air dan Etanol Bawang Putih (Allium sativumL.) terhadap Bakteri Gram Negatif dan Gram Positif yang Diisolasi dari Udang Dogol (Metapenaeus monoceros), Udang Lobster (Panulirus sp), dan Udang Rebon (Mysis dan Acetes), Bandung : Jurnal Biotika

Made Astawan, 1999, Ikan yang Sedap dan Bergizi, Jakarta: Tiga Serangkai

Nurwantorodan Abbas Siregar Djarijah, 1997, Mikrobiologi Pangan Hewani Nabati, Yogyakarta: Kanisius
Pamungkas, R.N, 2010, Pemanfaatan Lengkuas (Langkuas galanga) Sebagai Bahan Pengawet Pengganti Formalin, Malang : Universitas Negeri Malang.

Parwata OA, 2008, Isolasi dan Uji Aktifitas Anti bakteri Minyak Atsiri dari Rimpang Lengkuas, Jimbaran : Universitas Udayana.

Rhena Justicia Octovrisna, 2011, Pengaruh Berbagai Konsentrasi Larutan Jahe dan Lama Waktu Perendaman Terhadap Jumlah Total Mikroba Pada Ikan Bandeng, Jurnal Ilmiah, Semarang : Universitas Muhammadiyah Semarang.

Santoso, H.B, 2000, Bawang Putih, Edisi ke-12, Yogyakarta: Kanisius.

Tri Cahyono, 2014, Pedoman Penulisan Proposal dan Karya Tulis Ilmiah/ Skripsi (Edisi Revisi Ketiga), Purwokerto :P oliteknik Kesehatan Kemenkes Semarang, Jurusan Kesehatan Lingkungan Purwokerto.

Wiryawan KG, S Suharti \& M Bintang. 2005, Kajian Antibakteri Temulawak, Jahe dan Bawang Putih terhadap Salmonella typhimurium serta Pengaruh Bawang Putih terhadap Performans dan Respons Imun Ayam Pedaging, Media Peternakan 28. 